\title{
2011s-07 \\ Competitive Preferences and Status as an Incentive: Experimental Evidence
}

Gary Charness, David Masclet, Marie-Claire Villeval

\begin{tabular}{c}
\hline Série Scientifique \\
Scientific Series
\end{tabular}

\section{Montréal}

Janvier 2011

(C) 2011 Gary Charness, David Masclet, Marie-Claire Villeval. Tous droits réservés. All rights reserved. Reproduction partielle permise avec citation du document source, incluant la notice $($ ).

Short sections may be quoted without explicit permission, if full credit, including (C) notice, is given to the source.
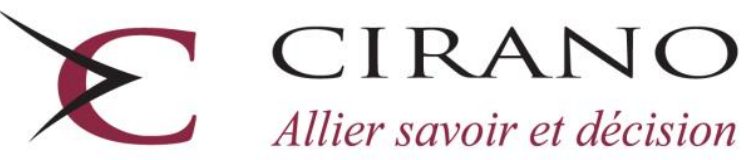

Allier savoir et décision

Centre interuniversitaire de recherche en analyse des organisations 


\section{CIRANO}

Le CIRANO est un organisme sans but lucratif constitué en vertu de la Loi des compagnies du Québec. Le financement de son infrastructure et de ses activités de recherche provient des cotisations de ses organisations-membres, d'une subvention d'infrastructure du Ministère du Développement économique et régional et de la Recherche, de même que des subventions et mandats obtenus par ses équipes de recherche.

CIRANO is a private non-profit organization incorporated under the Québec Companies Act. Its infrastructure and research activities are funded through fees paid by member organizations, an infrastructure grant from the Ministère du Développement économique et régional et de la Recherche, and grants and research mandates obtained by its research teams.

\section{Les partenaires du CIRANO}

Partenaire majeur

Ministère du Développement économique, de l'Innovation et de l'Exportation

\section{Partenaires corporatifs}

Banque de développement du Canada

Banque du Canada

Banque Laurentienne du Canada

Banque Nationale du Canada

Banque Royale du Canada

Banque Scotia

Bell Canada

BMO Groupe financier

Caisse de dépôt et placement du Québec

Fédération des caisses Desjardins du Québec

Financière Sun Life, Québec

Gaz Métro

Hydro-Québec

Industrie Canada

Investissements PSP

Ministère des Finances du Québec

Power Corporation du Canada

Raymond Chabot Grant Thornton

Rio Tinto

State Street Global Advisors

Transat A.T.

Ville de Montréal

\section{Partenaires universitaires}

École Polytechnique de Montréal

HEC Montréal

McGill University

Université Concordia

Université de Montréal

Université de Sherbrooke

Université du Québec

Université du Québec à Montréal

Université Laval

Le CIRANO collabore avec de nombreux centres et chaires de recherche universitaires dont on peut consulter la liste sur son site web.

Les cahiers de la série scientifique (CS) visent à rendre accessibles des résultats de recherche effectuée au CIRANO afin de susciter échanges et commentaires. Ces cahiers sont écrits dans le style des publications scientifiques. Les idées et les opinions émises sont sous l'unique responsabilité des auteurs et ne représentent pas nécessairement les positions du CIRANO ou de ses partenaires.

This paper presents research carried out at CIRANO and aims at encouraging discussion and comment. The observations and viewpoints expressed are the sole responsibility of the authors. They do not necessarily represent positions of CIRANO or its partners. 


\title{
Competitive Preferences and Status as an Incentive: Experimental Evidence
}

\author{
Gary Charness $^{\dagger}$, David Masclet ${ }^{+}$, Marie-Claire Villeval $^{\S}$
}

\begin{abstract}
Résumé / Abstract
Dans cet article, nous étudions la recherche de statut par les agents économiques dans un environnement où un meilleur statut ne procure pas nécessairement un avantage monétaire. Pour cela, nous avons réalisé une expérience en effort réel dans laquelle les agents sont amenés à fournir un niveau d'effort et sont informés de la performance de leurs collègues de travail. Nous observons que la plupart des gens ont un goût élevé pour la compétition et la recherche de statut au sein de leur groupe. Les individus augmentent leur niveau d'effort dès lors qu'ils sont informés de l'effort des autres. Certains sont même disposés à saboter l'effort des autres ou à accroitre artificiellement leur propre effort afin d'accroitre artificiellement leur statut.
\end{abstract}

Mots clés : recherche de statut, classement, préférences compétitives, expérience

In this paper, we investigate individuals' investment in status in an environment where no monetary return can possibly be derived from reaching a better relative position. We use a real-effort experiment in which we permit individuals to learn and potentially improve their relative position in terms of performance. We find that people express a taste for status. People increase their effort when they are informed about their relative performance, and some individuals pay to sabotage others' output or to artificially increase their own performance although they are paid a flat wage. Introducing the opportunity to sabotage others' output exerts a negative effect on performance. Such effects can be alleviated by inducing group identity that favors positive rivalry but discourages sabotage among peers.

Keywords: Status seeking, rank, competitive preferences, experiment

Codes JEL : C91, C92, M54, D63, J28, J31

\footnotetext{
* The authors thank Nagore Iriberri for comments on a previous version of this paper and participants at the World meeting of the ESA conference in Copenhagen and at the ASFEE conference in Grenoble. We are grateful to Elven Priour for programming the experiment. Financial support from the Agence Nationale de la Recherche (ANR-08-JCJC-0105-01, “CONFLICT" project, and ANR BLAN07-3_185547 "EMIR" project) is gratefully acknowledged.

$\dagger$ Department of Economics, University of California, Santa Barbara, 2127 North Hall, Santa Barbara, CA 93106-9210. E-mail: charness@econ.ucsb.edu.

† CREM, CNRS, University of Rennes, 7 place Hoche, 35000 Rennes, France, and CIRANO, Montreal, Canada. E-mail: david.masclet@univ-rennes1.fr.

${ }^{\S}$ GATE, CNRS, University of Lyon, 93 Chemin des Mouilles, 69130, Ecully, France, IZA, Bonn, Germany, and CCP, Aarhus, Denmark. E-mail: villeval@gate.cnrs.fr.
} 


\section{INTRODUCTION}

While standard economic theory assumes that individuals only care about their individual payoffs, there are many situations in which people exhibit a strong concern for social comparisons and status. In economics, social comparisons have been shown to influence both behavior (see for example Glaeser et al., 1996, on criminal activity; Duflo and Saez, 2002, on investment plans; Güth et al. 2001, Charness and Kuhn, 2007, Gächter and Thöni, 2009, and Clark et al., 2010, on effort in employer-employee relationships) and subjective well-being (Clark and Oswald, 1996; Clark et al., 2008; Brown et al., 2008; Ferrer-i-Carbonell, 2005; Luttmer, 2005; Azmat and Iriberri, 2010a, b). Social comparisons are especially important when people care about their status in their reference group. Theoretical models have shown that the willingness to pay for status influences efficiency and income redistribution (see for example Allgood, 2006, Hopkins and Kornienko, 2009). A few experimental studies in economics demonstrate both the importance given by individuals to status and how it affects behavior in negotiations (Ball and Eckel, 1996), markets (Ball and Eckel, 1998; Ball et al., 2001), coordination games (Eckel and Wilson, 2007), and organizations either in cooperative settings (Kumru and Vesterlund, 2008; Eckel et al., 2009) or in competitive settings (Huberman et al., 2004; Rustichini and Vostroknutov, 2008).

However, none of these studies investigates people's investment in status seeking in an environment without any expected monetary return from such activity. Indeed, in most of the experimental studies cited above, status is given exogenously and it is provided without any cost (with the exception of Ball and Eckel, 1998; Huberman et al., 2004; Rustichini and Vostroknutov, 2008). In this paper, we define status as the individuals' relative standing in their

group and we isolate the pure willingness of individuals to invest in status-seeking activities and 
its impact on real effort. Everyday life provides numerous examples in which people invest resources in status seeking to be at the top of the social scale. Human-resource managers also take advantage of this concern for social position through policies such as assigning symbolic rewards to the employee of the month. Status seeking may be related to the desire for dominance in competition. This has been documented both in animals and in humans, as dominance better secures the access to food or to mates. ${ }^{1}$ In the same vein, the existence of competitive preferences identified in economics (Charness and Grosskopf, 2001; Charness and Rabin, 2002; Abbink and Sadrieh, 2009; Abbink, Masclet, and van Veelen, 2009) may motivate people to engage in such status-seeking activities. ${ }^{2}$ However, we would like to be clear that status seeking and competitive preferences are not identical. Status seeking typically involves some form of public recognition, while a taste for competitive preferences does not depend on such recognition. Of course, receiving a symbolic reward may matter even in the absence of observability by others if it affects self-esteem. In this study, however, we are chiefly interested in social status and we do not aim at disentangling these two dimensions.

While one motivation for costly status seeking is the expectation of (eventual) monetary benefits, this behavior is also observed when no immediate or delayed monetary return can be derived from the competition. Indeed, many people engage in behavior such as investing in costly status symbols and conspicuous consumption of positional goods (Duesenberry, 1949; Veblen, 1949; Frank, 1985), or striving for status and public display of status as a goal in itself (Huberman et al., 2004). As shown in Rustichini (2008), humans may be willing to make costly

\footnotetext{
${ }^{1}$ Status seeking may be also related to matching among individuals. For example, if social status signals nonobservable abilities, it may help people to match with people of similar ability, which will be payoff-maximizing in case of complementary interactions (Rege, 2008). We do not investigate this dimension in our paper.

${ }^{2}$ In one allocation task in Charness and Grosskopf (2001), a person could choose any amount between 300 and 1200 for the other person while receiving 600 for herself regardless of her choice. A number of people choose to allocate less than 600 . One example was the individual who chose 599 for the paired participant.
} 
decisions when engaged in a contest if the outcome of the competition says something about the underlying factors of the ranking, i.e. if a higher (lower) rank in terms of performance means a higher (lower) rank in the social scale. Individuals may therefore make costly choices to improve their status if they believe that others will interpret the outcomes of past contests as a signal of their intrinsic value and their status in the society.

It is difficult if not impossible to use field data to determine the extent to which individuals are willing to invest in resources to improve their status aside from potential (eventual) financial remuneration, and how this behavior is affected by the conditions in which status can be improved. Survey data have trouble identifying status-seeking activities and since they cannot precisely delineate reference groups, it is difficult to know to whom individuals compare themselves. By controlling the environment and the composition of the reference group, experimental methods offer the possibility of directly evaluating the individual's willingness to invest in status seeking.

Our aims in this study are three-fold. First, we study whether individuals care about their status in a setting where status derives from receiving more or less salient information about their relative position in their group (in the case of more salient information, we assign positive or negative symbols for the highest or lowest rank, respectively). Relative position is here determined by work performance in a real-effort task. Status seeking may motivate people to perform better (Frank, 1988). In our environment, people can compete to accumulate positive symbols or to avoid negative symbols, but not in order to receive better pay. Second, we study the degree to which individuals are willing to pay to increase their performance in their reference group in order to improve their rank and their status. And third, we analyze how any such investment is affected by the feasible mechanism for status improvement. 
Indeed, one can improve one's relative position not only by exerting higher effort to outperform others (see Azmat and Iriberri, 2010a, and Blanes i Vidal and Nossol, 2009 for field data, and Azmat and Iriberri, 2010b and Eriksson et al., 2009, for experimental evidence), but also by using other strategies. Examples of own artificial performance improvement include doping (see Preston and Szymanski, 2003), forgery, use of ghost-writers and plagiarism. Competition has been shown to favor unethical behavior (Shleifer, 2004), and Schwieren and Weichselbaumer (2010) show experimentally that a competitive environment encourages people to cheat to improve their own performance. Alternatively, people may also improve their relative position in a group by sabotaging the performance of others.

In economics, sabotage is usually motivated by the agent's willingness to increase the probability of receiving the winner's prize in tournaments (Lazear, 1989; Chen, 2003; Harbring and Irlenbusch, 2008; Harbring et al., 2007); this is also true in our environment, except the prize is purely symbolic. In social psychology, sabotage is more broadly related to the analysis of interpersonal destructive deviance at work that causes harm to others (Berry et al., 2007; Tziner et al., 2006). Here, while sabotage harms others by destroying their output, it reduces the earnings of the agent who chooses sabotage (this is in contrast with Rustichini and Vostroknutov, 2008, in which rank can improve by subtracting money from another player's earnings). To the best of our knowledge, we provide the first paper on sabotage and artificial improvement of performance in the context of a flat pay scheme. With our design, we can measure whether players are more likely to sabotage others' performance or to artificially improve their performance and their respective consequences on behavior and efficiency.

To preview our results, our data show that even when wages are fixed, many subjects exhibit competitive behavior. Individual performance is significantly influenced by feedback on 
one's relative position in the group, as people tend to exert significantly more effort when they receive information about their rank. A striking result is that some people are willing to pay for status improvement without any instrumental monetary considerations, sacrificing money to potentially improve their rank. We also find that introducing the opportunity to sabotage others' output has a negative impact on performance.

In addition, there is evidence of bonding: if people from the same school are more likely to improve their own relative position artificially, they are less likely to sabotage than when matched with people from other schools. This indicates that group identity favors positive rivalry but discourages destructive competition. Overall, our findings provide evidence of competitive preferences in non-monetary competitive settings. Some people value status per se, perhaps because they believe that their relative position in a group serves as a signal to others about their intrinsic value.

The remainder of the paper is organized as follows. Section 2 describes the experimental design. Section 3 presents our behavioral conjectures about the expected treatment effects. The results of the study are presented in section 4 . Section 5 contains our concluding remarks.

\section{EXPERIMENTAL DESIGN}

\subsection{Treatments}

Our experiment consists of four different treatments with ten periods each and is based on a between-subject design. In our baseline treatment, each person is matched with two other

people. We use a stranger matching protocol, so that groups are randomly reformed at the beginning of each new period. Participants are informed that they will be paid a flat wage of 10 
Experimental Currency Units (with 10 ECU equal to one Euro) at the beginning of each of 10 periods, so that it is common information that wage is uncorrelated to performance. ${ }^{3}$ They have the option of performing a task during a fixed time of two minutes; this task consists of decoding sets of one-digit numbers into letters from a grid of letters that is displayed on the computer screen (see the screenshots in the Appendix, where sample instructions are presented). In each new period, a different grid of letters and different decoding numbers appear. ${ }^{4}$

Participants must press a button to start a new period (and immediately receive the wage for the period). Once this is done, they can stop working at any time during the course of the period and can resume work at will; they can also choose not to perform the task at all. We provide the participants with alternative leisure activities on the job. Two magazines are provided in each cubicle and the instructions clearly indicate that people are allowed to read these magazines or any personal documents they have brought in their bags. ${ }^{5}$ The participants are continuously informed of their current number of correct answers. If a submitted answer is not correct, the individual is informed that her response was not correct and the same letter is displayed until the correct answer is provided. Once the two minutes have elapsed, a vertical bar is displayed on the screen; its height indicates the total number of correct answers. In this treatment, people receive no feedback about the performances of the other two group members.

The ranking treatment is identical to the baseline except that the computer displays three vertical bars corresponding to the performance of each of the three group members at the end of each period on the screens of the group members. Each person is therefore able to see her

\footnotetext{
3 This is justified by our willingness to investigate people's investment in status seeking in a setting where no monetary return can be expected from such activity. Experiments with flat wage payment schemes include notably Falk and Ichino, 2006; Dohmen and Falk, 2010 and Greiner, Ockenfels, and Werner, 2010.

${ }^{4} \mathrm{We}$ chose a fastidious and boring task to induce sufficient disutility to the subjects.
} 
relative performance. In one ranking sub-treatment, people also received positive or negative symbols to materialize this ranking. Specifically, the worker who has performed the best in her group receives a "gold medal" while the lowest performer gets a "donkey hat". At the beginning of each period, each player can see the profile of her two co-workers and this is made common information in the instructions. The profile of each subject includes a historical record of all symbols received throughout the previous periods, in order to build a social image based on the accumulation of displayable trophies (gold medals) or stigmata (donkey hats). In order to isolate the effects of these devices, we also conducted a variant called the ranking treatment without symbols. This treatment is identical to the ranking sub-treatment described above except that highest and lowest relative positions are not assigned visual symbols. In the profile box displayed at the beginning of each period, we indicate for each person the number of times she has been ranked first and last in previous periods.

The subjects' profile also includes their gender and their school, as in the baseline treatment. This also allows us to investigate the importance of in-group effects and whether knowing that one shares similar characteristics with the other members of one's group influences decisions. Indeed we know the potential importance of group identity and bonding from the literature in both social psychology and economics (Tajfel et al., 1971; Brewer, 1999; Akerlof and Kranton (2000), Halevy et al., 2007; Charness et al., 2007; Chen and Li, 2009). Our expectation is that if people are biased in favor of their group, they should sabotage less when matched with participants from the same school, same status or same gender.

The redemption treatment is identical to the ranking treatment, except that the participants are informed in the instructions that we add a second stage in which they can modify

\footnotetext{
5 See Dickinson (1999) for an experimental study of on-the-job leisure. In the field, leisure at work takes multiple
} 
their performance. Indeed in this stage, people have the opportunity to (simultaneously) purchase extra units of 'output' to artificially increase their performance and possibly their rank in the performance distribution. They can buy from 0 to 20 units of output that will be added to their original performance; the cost of each unit is $0.5 \mathrm{ECU}$ and this cost is deducted from the person's payoff. At the end of this stage, the computer program computes and displays the net performance of each group member, and the symbols associated with this net performance (the donkey hat for the lowest performer and the medal for the best performer).

The sabotage treatment is identical to the redemption treatment except that in the second stage participants are informed in the instructions that they can pay to reduce the performance of their co-workers. They can assign from 0 to 20 costly points to each of the other members of their group 'to reduce their score'. Each point assigned by player $i$ to player $j$ reduces player $j$ 's performance by one unit of output and this may modify the provisional ranking resulting from performing the task in stage one. Assigning points is equivalent to sabotage (although the term is not used in the instructions). While player $j$ 's earnings are unaffected by receiving sabotage points, a participant who chooses sabotage incurs a direct cost of $0.5 \mathrm{ECU}$ per point of sabotage that is subtracted from the flat wage to determine the final earnings for the period. We chose the same cost for each unit purchased in the two treatments. While each sabotage or redemption point costs the same, it should be acknowledged that in some cases, one redemption point allows the subject to improve her position relative to the two other group members, whereas one sabotage point targets only one person. This brings up the issue of relative cost. ${ }^{6}$ Note that our

forms: surfing the net, long coffee breaks, office gossiping, etc.

${ }^{6}$ Some studies have investigated in the context of public-good games the extent to which the decision to punish is influenced not only by the cost of punishment but also by its impact on the target. The evidence is mixed. Anderson and Putterman (2006) find that the demand for punishment is decreasing in its price. In Nikiforakis and Normann (2008), contributions to the public good increase monotonically in the effectiveness of punishment. In contrast, 
results do not seem to support a cost-efficiency hypothesis since we should expect more redemption points than sabotage, which contrasts with what we observe.

As in the redemption treatment, people can observe any change in the performance of the three group members at the end of the second stage. However, while people can see directly if their group members have artificially increased their own score in the redemption treatment, they are not informed about who has sabotaged their output. ${ }^{7}$ It is also important to note that buying points (both redemption and sabotage points) is associated with status seeking as the trophies earned will be displayed on the screen of the group members after groups have been re-matched in the next periods. Once a new group has been formed, everybody is able to observe the symbols accumulated by each other group member in the past but no one is informed about how these symbols have been acquired. Indeed, as in the ranking treatment, participants in the redemption and sabotage treatments are informed that at the beginning of each new period their profile will be displayed on the screen of their group members, including the number of donkey hats and gold medals earned in the previous periods. ${ }^{8}$

\subsection{Experimental procedures}

The experiment consists of 24 sessions of ten periods each. 12 sessions were conducted at the CREM-CNRS (LABEX) institute of the University of Rennes 1 and 12 others were conducted at

\footnotetext{
Masclet and Villeval (2008) find that people pay more to increase the harm imposed on targets when punishment has a lower impact. The same result is found in Falk, Fehr and Fischbacher (2005) in cooperation games.

${ }^{7}$ We note that the second stage of both the redemption and sabotage treatments involves a strategic decision if people care about their status in the group; in this case, if one believes that others will be spending money for redemption or sabotage, this may well increase the likelihood that one also spends money on redemption or sabotage (in order to at least preserve status). While we cannot know whether the motivation for engaging in redemption or sabotage reflects strategic concerns, in any case the underlying motive for purchasing points is that people care about status.

${ }^{8}$ Under the assumption that people can perfectly observe each other in peer groups, we deliberately allowed individuals to observe any change in the performance of the three group members. We would most likely observe more sabotage (redemption) with some degree of anonymity, so that our results may represent a lower bound for sabotage (redemption) in the laboratory.
} 
the GATE-CNRS institute of the University of Lyon, France. Between nine and 15 individuals took part in each session, for a total of 345 participants who were invited via the ORSEE software (Greiner, 2004); no individual participated in more than one session. The participants were undergraduate students from a variety of majors including business, economics, law, engineering, medicine and literature. Table 1 displays summary information about the sessions and includes the session number, the location, the number of people and 3-person groups in the session, and the treatment.

[Table 1 about here]

The experiment was computerized and the scripts were programmed using the Z-tree platform (Fischbacher, 2007). The experiment lasted on average 90 minutes and each subject earned an average of 14.74 Euros, including a show-up fee of 5 Euros.

\section{BEHAVIORAL HYPOTHESES}

To illustrate what we expect to happen in our experiment, we present in this section some behavioral hypotheses based on individuals' concerns for status and social ranking.

Consider first the baseline treatment. If one assumes that individuals are only interested in maximizing their own payoff, the theoretical prediction is straightforward: the minimum effort possible should be exerted in the baseline treatment. ${ }^{9,10}$ The same prediction should also apply to

\footnotetext{
${ }^{9}$ Note that the minimum effort provided is not necessarily zero if one assumes that there is some intrinsic motivation for working that depends on individual preferences (see Kreps, 1997; Baron, 1988; Dohmen and Falk, 2010; Falk and Ichino, 2006; Eriksson et al., 2009). Psychologists and sociologists have long emphasized the importance played by intrinsic motivation at work. Intrinsic motivation includes self esteem, interest and pride in one's work, and an innate sense of duty to "honor one's contract" (Kreps, 1997; Baron, 1988; James, 2005; Ellingsen and Johanesson, 2008) but can also be related to the worker's response to extrinsic motivations including fear of discharge. It should be noted that our goal in this experiment is not to identify the determinants of performance in the baseline but to investigate the impact of ranking and manipulation of status on work effort.

${ }^{10}$ Several empirical studies of the gift-exchange game have shown that, despite the absence of any penalty for shirking, workers do respond to flat wages by exerting non null effort levels and that an increase in flat wage raises
} 
the ranking treatment. Turning next to the redemption and sabotage treatments, we can easily see by backward induction that the only subgame-perfect equilibrium of the game, whether played once or finitely repeated, is for no participant to either work or purchase redemption or sabotage points.

One may however relax some assumptions and consider that participants may be motivated by their relative performance, enjoy outperforming others, and desire even the modest symbols of status offered in our experiment. There is strong evidence that people care not only about their own payoffs but also about social comparisons and status (Ball and Eckel, 1998; Huberman et al., 2004; Kumru and Vesterlund, 2008; Rustichini, 2008; Eckel et al., 2009; Gächter and Thoeni, 2009; Clark et al., 2010). These studies have focused on the effects of income comparison but very little attention has been paid to performance comparison, particularly in the absence of career concerns. A few studies show that providing feedback on others' performance induces positive effects on individuals' effort under a flat pay scheme. ${ }^{11}$ Both Falk and Ichino (2006) and Mas and Moretti (2009) show that peer effects increase productivity when workers can observe another worker's output, which supports the idea that subjects would incur disutility when they fall behind their fellow workers. Kuhnen and Tymula (2008) also observe that agents work harder when they observe their ranking, suggesting an impact of feedback on self-esteem and a desire for dominance. Based on these previous observations we can write the following hypothesis:

worker's effort (Fehr, Kirchsteiger and Riedl, 1993; Fehr, Gächter and Kirchsteiger, 1997; ). Field experiments have confirmed these findings to some extent (see Gneezy and List, 2006; Kube et al., 2008; Cohn et al., 2009). Interestingly, these findings are robust to the introduction of most unfavorable conditions such as the absence of repeated relationships or exogenously fixed wages (Falk and Ichino, 2006; Kuhnen and Tymula, 2008; Dohmen and Falk, 2010; Greiner et al. 2010).

11 Similar positive effects of feedback on relative performance have been identified under piece rate payment schemes and in tournaments (Azmat and Iriberri, 2010a,b; Hannan et al., 2008; see also Eriksson et al., 2009, who find more mitigated results). 
H1: In a flat wage environment, providing feedback on others' performance brings positive effects on performance.

Our second conjecture is that, for similar reasons as those presented above, some participants may be willing to buy sabotage or redemption points although they are costly, in order to increase their status. We are not aware of any study on redemption or sabotage activities in settings with a flat payment scheme. Sabotage activities have been usually studied in tournaments with monetary prizes (Lazear, 1989, Konrad, 2000; Chen, 2003; Garicano and Palacios-Huerta , 2006; Harbring et al., 2007; Falk et al., 2008; Harbring and Irlenbusch, 2008; Carpenter et al., 2010). These studies show that if relative comparisons encourage effort, they also lead to sabotage. The rationale of sabotage can be found in the willingness to earn more (as its frequency increases in the size and spread of tournament prizes) but also in the desire to win per se. Our conjecture is that if people value their status sufficiently high and if they have sufficient competitive preferences and desire for dominance (Rustichini, 2008), they may be willing to exert sabotage at a cost under a flat wage scheme. Similarly, we anticipate that individuals may be willing to artificially increase their own performance. Due to the negative externalities associated with sabotage activities, we expect, however, to observe more redemption than sabotage activities. This conjecture is summarized in $\mathrm{H} 2$.

$\mathrm{H} 2$ : Individuals with competitive preferences will buy sabotage and/or redemption points to increase artificially their ranking. More redemption points should be bought due to the negative externalities associated with sabotage.

Our last conjecture is about the effects of redemption and sabotage points on further performance. We conjecture that the opportunity of sabotage may have strong negative effects on performance. Such destructive effects have been identified in the context of tournaments. The efficiency of an organization is reduced for three main reasons: the most able individuals are those who are sabotaged more often (Chen, 2003); sabotage leads workers to provide less 
effort because they expect to become the victims of sabotage (Carpenter et al., 2010); and sabotage may lead to retaliation, in particular if the saboteur's identity is revealed (Harbring et al., 2007). In the context of a flat payment scheme, sabotage entails no monetary consequences on the victims and could have less negative impact on effort than in tournaments. However, if workers have an intrinsic motivation to exert effort although being paid a flat wage, we suspect that being sabotaged will negatively affect the intrinsic motivation of these individuals. Therefore, we conjecture that the opportunity for sabotage in our environment will induce a significant decrease of performance by destroying output and by discouraging high productive workers. In addition, even if workers are re-matched after each period, sabotage may lead to blind revenge, as observed in several money burning experiments. We do not expect such a negative impact of redemption activities on average performance, as they do not affect directly any co-worker's output. Indirectly they may however reduce the motivating impact of feedback on relative performance, as people know that this information can be biased. This is stated in conjecture 3 .

H3: The opportunity for sabotage may have a detrimental impact on initial performance. The impact of redemption activities might be also negative, but only indirectly and to a moderate degree.

\section{EXPERIMENTAL RESULTS}

This section presents a comparative analysis of performance across treatments, before analyzing the individuals' willingness-to-pay for status in the redemption and sabotage treatments. Last, we examine the overall impact of status-seeking activities on individual effort decisions. 


\subsection{Performance}

Table 2 provides some summary statistics on average performance in each treatment and Figure 1 displays the distribution of effort by treatments.

\section{(Table 2 and Figure 1 about here)}

Figure 1 summarizes the data on initial performance. It indicates the average level and the confidence interval of initial (i.e. before sabotage or redemption) performance in each treatment across periods.

Figure 1 shows that on average people score 23.15 correct answers per period under the baseline treatment. Our data also indicate that there is a non-negligible part of subjects who choose to perform no task at all. The average frequency of the no-effort choice is $7.77 \%$ in the baseline.

Interestingly, both Table 2 and Figure 1 indicate that informing participants about their relative performance produces a positive and significant incentive on work effort in the ranking treatment. As Figure 1 shows, the introduction of feedback on the performances of others enhances performance, as the whole distribution shifts up in the ranking treatment compared with the baseline treatment. On average people perform 4.5 units of output more in the ranking treatment than in the baseline. The average performance is 27.65 tasks in the ranking treatment (pooling both variants of this treatment since, as we shall see, there is no significant difference between them) with less variability. ${ }^{12}$ A Mann-Whitney pairwise statistical test using sessionlevel data indicates that this difference is significant $(z=-2.263, p=0.024)$. We also observe that

\footnotetext{
12 A Mann-Whitney pairwise statistical test comparing average performance in the two variants of the ranking treatment (with and without the assignment of symbols) indicates no significant difference $(z=-1.492, p=0.136)$. This finding suggests that status symbols per se have little effect on performance compared with simple feedback about relative performance. In the remaining of the section we therefore pool data of both ranking treatments.
} 
introducing feedback reduces both the variability in performance and the number of no (or very low)-effort choices, providing status-seeking incentives for workers to perform higher effort when information is available. The average frequency of the no-effort choice in the ranking treatment is $2.36 \%$, which is significantly lower that the frequency of no-effort in the baseline ( $\mathrm{z}$ $=-2.078, \mathrm{p}=0.037$, two-tailed). These findings are consistent with hypothesis $\mathrm{H} 1$.

Introducing an opportunity to increase artificially one's own outcome does not change the average initial performance compared with the ranking treatment. The average score is 25.86 in the redemption treatment, which is not significantly different from the ranking treatment $(\mathrm{z}=-$ 1.347, $\mathrm{p}=0.178)$. A weakly-significant difference is however found between the redemption and the baseline treatments $(z=-1.715 ; \mathrm{p}=0.08)$. People actually produce 2.71 units more in the redemption treatment than in the baseline (the difference amounts to 3.49 units after the use of redemption points). Finally, allowing people to sabotage decreases initial effort. On average people score 24.19 units of output per period in the sabotage treatment. The difference in the actual performance between the baseline and the sabotage treatment is only 1.04 units (with no difference at all after the use of sabotage). A Mann-Whitney pairwise statistical test indicates that this difference is not significant $(\mathrm{z}=-0.980, \mathrm{p}=0.327)$. The average frequency of the noeffort choice is $8.20 \%$ in the sabotage treatment, which is similar to the baseline $(\mathrm{z}=-0.245, \mathrm{p}>$ 0.10). Finally, a Mann-Whitney test indicates that people actually produce significantly less in the sabotage treatment than in the ranking treatment $(\mathrm{z}=-1.900, \mathrm{p}=0.057)$ and less than in the redemption treatment although not significant $(\mathrm{z}=0.522, \mathrm{p}=0.601)$. These findings are consistent with our hypothesis H3.

Figure 2 shows the time path of average initial performance by period in all treatments. It indicates that the evolution of performance over time differs also across treatments. 


\section{(Figure 2 about here)}

Figure 2 indicates that the average performance is very similar across treatments in the first period of the game. The sharp increase in the average performance between period 1 and period 2, observed in all treatments, may simply reflect a learning effect. Figure 2 shows that there is little difference in performance between treatments in the first half of the game. In sharp contrast, strong differences across treatments emerge after period 5. These findings are confirmed by Mann-Whitney tests. ${ }^{13}$ After period 5, average performance decreases in both the baseline and the sabotage treatments while it remains rather stable over time in the ranking and redemption treatments.

This evolution suggests that status seeking prevents performance from declining over time in the ranking and redemption treatments. The decline of performance in the sabotage treatment might be due to the fact that the positive effect of status concern on performance is more than offset by the discouragement produced in some players by this destructive environment. This is consistent with our hypothesis H3.

Taken together, these findings reveal that informing participants about their relative performance in the ranking treatment induces a positive effect on work effort compared with the baseline treatment. Introducing the opportunity to artificially change one's own relative performance does not lead to higher work effort in the redemption treatment but it decreases performance in the sabotage treatment compared with the ranking treatment. These findings may be explained by a decline of intrinsic motivation for working in such destructive environments.

\footnotetext{
13 While the difference between the ranking and the baseline treatments in the first five periods is marginally significant, none of the other differences are significant. In contrast, almost all differences are statistically significant in the last five periods. Compared with the baseline, people work harder both in the ranking $(z=-2.546$, $p=0.011)$ and in the redemption treatments $(z=-2.091, p=0.036)$, which supports our conjecture H1. No significant difference is found between the sabotage and the baseline treatments $(z=-0.980, p=0.327)$.
} 
The econometric analysis reported in Table 3 provides more formal support for these results. The dependent variable is the actual individual performance. Since there are 10 observations for each participant, we estimate econometric models with random effects. Model (1) is a Generalized Least Squares model with robust standard errors clustered at the session level to control for serial correlation within each session. The independent variables include treatment dummies, with the baseline as the reference category, and a dummy variable equal to 1 if the observation belongs to periods 6 to 10 , and 0 otherwise. Model (2) reports similar estimates with a control for demographic variables (gender, being a student at the University versus being in another school, studying economics or not). To check the robustness of our results, we have also estimated two random-effects Tobit models (models (3) and (4)), since a number of observations are left-censored (see the distribution of performances by treatment in Figure 1. In model (4), we add several interaction variables to the previous independent variables to control for trend differences across treatments in the second half of the game.

\section{[Table 3 about here]}

Model (1) shows that providing information on one's own relative performance has a positive and significant effect on absolute performance. All else equal, players' effort is predicted to increase by 4.51 units $(19.71 \%$ of the coefficient of the constant term) in the ranking treatment compared with the baseline. The dummy variable "redemption" also captures a positive and significant coefficient, indicating that people also provide more effort in this treatment than in the baseline. Performance is 2.71 units higher (11.84\% of the coefficient of the constant term) than in the baseline. A $t$-test indicates that there is no significant difference between the ranking and redemption treatments $(p=0.184)$, suggesting that introducing the opportunity to artificially 
increase one's own performance does not lead to an improvement in average performance. Introducing the opportunity to sabotage leaves unchanged the average performance obtained in the baseline, suggesting that the positive effects of ranking are offset by the introduction of sabotage activities. Model (2) reports similar results, indicating that these effects are robust to the introduction of demographics; similar results are also found with model (3), a Tobit model.

Model (4) indicates that the coefficients associated with the interaction variables ranking*periods 6-10 and redemption*periods 6-10 are positive and significant at the $1 \%$ level. These results confirm the fact that status concern mitigates the decline of performance observed in the baseline treatment in the second half of the game. The interaction variable sabotage*periods 6-10 is only marginally significant, probably because a large part of the impact of status concern is offset by the refusal of some subjects to work in such an environment. These findings support our behavioral predictions.

\subsection{Investment in status-seeking activities}

People are willing to pay to improve their performance artificially or for reducing the performance of others. On average in a period, the subjects buy 1.08 sabotage points (S.D. = 2.94) and 0.77 redemption points (S.D. = 2.15). A Mann-Whitney pairwise test indicates no significant difference in the number of points assigned between the sabotage and the redemption treatments across all periods $(z=0.733, p=0.460)$ or in the final period alone $(z=1.155, p=$ 0.248). The high standard deviation indicates, however, a great deal of heterogeneity among individuals. In fact, only a modest proportion of participants (14.20\%) purchase sabotage points in a period, but those who do so buy an average of 5.25 points; this represents $26.25 \%$ of their income for the period. This amount of sabotage looks relatively low and appears to be rather 
realistic, as only few people in the field are expected to exert sabotage activities. These findings are also consistent with previous studies showing that if sabotage happens it generally remains at a moderate level. Similarly, $11.90 \%$ of the subjects pay to increase their performance, purchasing 4.58 points on average (22.90\% of their income for the period).

To better understand the willingness-to-pay for status, we examine successively the determinants of sabotage and redemption behavior.

\section{Status seeking and sabotage}

Table 4 provides information on the determinants of sabotage points by reporting the estimates from random-effects Tobit models. The dependent variable is the total number of sabotage points assigned by player $i$ to player $j$. The independent variables include the subject's actual performance that corresponds to the score of player $i$ in the first stage of the game. It also includes the squared value of the actual performance to test for potential non-linearity in the relationship between sabotage and performance. We add several variables capturing the subject's position in the performance distribution, and include a dummy variable for periods 6 to 10. ${ }^{14}$ We also control for demographics variables and the characteristics of the two co-workers to identify the presence of in-group effects. ${ }^{15}$

\footnotetext{
${ }^{14}$ The ank $_{i}$ variable corresponds to the relative position of subject $i$ in the performance distribution at the end of the first stage of each period; it is equal to 1 for the highest position, 2 for the intermediate position, and 3 for the lowest position in the distribution. The $\operatorname{rank}_{i}^{x}$ variable is equal to 1 if the individual is in relative position $x$ in the distribution, and 0 otherwise (with $x=1,2$ or 3 for the highest, intermediate and lowest position, respectively). The interaction variable $\operatorname{rank}_{i}{ }^{2}{ } \operatorname{rank}_{j}{ }^{l}$ captures the situation where $i$ occupies the intermediate position while the $j$ has the highest rank. The difference in performance between $i$ and $j$ is also included. Equal performance is equal to 1 if the performance of both subjects is equal, and 0 otherwise. The negative difference variable corresponds to the absolute value of the difference between the performance of $i$ and $j$ if $i$ 's initial performance is lower than $j$ 's performance, and 0 otherwise. The interaction variable low negative difference takes the absolute value of the difference between $i$ and $j$ when this difference is less than 5 units.

${ }^{15} \mathrm{We}$ also controlled for demographics variables and for the characteristics of the two other co-workers. More precisely, same school is equal to 1 if group members belong to the same school or university, and 0 otherwise. Same gender takes the value 1 if all group members are either males or females, and 0 otherwise. Last, average medals ${ }_{-i}$ (average hats $_{-I}$ ) indicates the current average number of gold medals (donkey hats) received by the two other group
} 


\section{[Table 4 about here]}

Table 4 illustrates the relationship between own performance and the decision to sabotage others. The initial performance variable captures a positive and significant coefficient, suggesting that the harder one works, the more one sabotages. This indicates that the subjects who sabotage are also those who are competitive and care about their rank. However, this relationship between performance and the decision to sabotage is non-linear. The reason is that the agents who exert a high performance need less sabotage to improve their rank. This is confirmed by the positive coefficient associated with the rank of the subject. After controlling for performance, this positive effect of rank indicates that the subjects who are not the best performers at the end of the first stage are more likely to pay to sabotage. Similarly model (2) in Table 4 indicates that being in the intermediate position $\left(\operatorname{rank}_{i}^{2}\right)$ or in the lowest position $\left(\operatorname{rank}_{i}^{3}\right)$ induces people to assign significantly more sabotage points than if they have attained the highest performance in their group. No significant difference is found between these two coefficients $(p=0.523)$. Including demographic variables leave these results unchanged (see model (3)).

Do people sabotage to reach the highest position or to avoid getting the lowest one? The $\operatorname{rank}_{i}^{2}$ variable is no longer significant when the interaction variable $\operatorname{rank}_{i}^{2}{ }^{*} \operatorname{rank}_{j}^{1}$ is included, while the coefficient of this interaction variable is positive and significant. This suggests that those who are in the intermediate position assign points only to those who are in the highest position in order to replace them in the highest position. Additionally, we find a positive and significant effect of the interaction variable " $\operatorname{rank}_{i}^{3}{ }^{*} \operatorname{rank}_{j}^{2}$ " in estimate (4). Controlling for this variable, $\operatorname{rank}_{i}^{3}$ is no longer significant, suggesting that those who are in the lowest position only assign points to those who are in intermediate position in order to avoid keeping the lowest

members in the previous periods. This variable is included to test whether being in a group of winners or losers 
position. Results from model (5) also support these findings. People assign more sabotage points when a co-worker's performance is equal or slightly higher.

Belonging to the same school as the other group members reduces the willingness to sabotage. A possible interpretation is that people are reluctant to sabotage their peers because of in-group preferences. However, belonging to the same gender does not generate the same behavior, suggesting that being of the same gender confers only a weaker sense of group identity. Average cum hat $t_{-i}$ has a significant and negative coefficient, indicating that the presence of low-status co-workers reduces the subjects' willingness to pay for sabotage, probably because it is easier to outperform them naturally. Finally, having received sabotage points in previous period has no significant impact, indicating that sabotage is not motivated by revenge (which is not surprising since groups are re-matched after each period).

To summarize, these findings indicate that subjects who pay to sabotage co-workers are also those who work hard and are highly competitive. However, this relationship is non-linear since the agents with the highest performance need not sabotage to improve their rank. Another interesting finding is that agents sabotage only those whose performance is close to theirs while they tend to give up when the difference in performance relative to the co-worker is too large. Finally, our data suggests the presence of an in-group bias, as belonging to the same school reduces the subjects' willingness to sabotage.

\section{Status seeking and redemption}

Table 5 reports the results from random-effect Tobit regressions on the determinants of redemption decisions. The dependent variable is the total number of redemption points subject $i$

influences the decision to sabotage others. 
buys to artificially increase her performance. The independent variables include most of the variables presented in Table 4. The negative difference variable is the absolute value of the difference in performance between person $i$ and the person with the next-higher performance, and is 0 otherwise. The equal performance variable is equal to 1 if subject $i$ 's actual performance is identical to the actual performance of at least one other group member. It is intended to capture the effect of the willingness to differentiate oneself from equals.

Table 5 reports very similar results to those obtained in Table 4 . The higher is the actual performance, the higher is the willingness-to-pay for redemption points. We also find an inverted U-shaped relationship between actual performance and the number of purchased redemption points. The $\operatorname{rank}_{i}^{2}$ and $\operatorname{rank}_{i}^{3}$ variables have significant positive coefficients, indicating that people buy more redemption points when they occupy the intermediate or the lowest position in the performance distribution compared with the people who occupy the highest position. Column (4) of Table 5 also shows that people buy redemption points to differentiate themselves from others, when they have equal actual performance; the time trend is negative. Last, belonging to the same school has a positive and significant impact on the willingness of people to increase their performance artificially. As we observed the opposite regarding the willingness to sabotage others, one interpretation is that in a group of peers people are particularly competitive, provided that being so does not harm others, in the sense of 'destroying' their production.

\subsection{The impact of status seeking on effort}

The rank in the distribution of performance and status-seeking activities in the group in the previous period may be important determinants of subsequent performance. We did not include 
these variables in the regressions reported above to avoid any endogeneity bias. We now estimate the determinants of changes in individual performance between period $t$ and period $t+1$ in separate random-effects Generalized Least Squares regressions. The independent variables include the same controls for the individual's rank in the distribution as in the regressions reported above. In addition, we include several variables to test for the influence of changes in the relative position of a subject in the distribution of performance due to status-seeking activities in the previous period. In particular, $\operatorname{rank}_{i}^{3}$ in $(t-1) *$ change is equal to 1 if the subject has ended up in the lowest rank in period $t$ - 1 while she had a higher rank at the end of the first stage of the previous period, and 0 otherwise. We also include the number of sabotage points received by the subject in the previous period and the number of redemption points purchased by the subject in $t$-1. In addition, we control for the standard demographic variables. Table 6 reports the results of these regressions.

\section{[Table 6 about here]}

Table 6 indicates that having the lowest rank in the distribution in period $t-1$ leads people to increase their effort in the next period. This is interesting since effort is increased without any additional monetary incentive, which suggests that performance comparisons support intrinsic motivation. In contrast, consistent with previous findings, being a victim of sabotage has a significant negative impact on future effort. Finally, Table 6 indicates that those who sabotage and those who purchase redemption points tend to exert more effort in subsequent periods. This suggests that competitive preferences motivate the people who are willing to reach the highest rank in their group both to exert productive effort even when paid a flat wage and to use artificial and costly means to improve their relative position in their group even when unfair to others. 


\section{CONCLUDING REMARKS}

There are many examples in everyday life at work in which people invest resources in wasteful activities to improve their own relative position in their reference group or to decrease the relative position of others. This may lead to interpersonal or organizational deviance and to illegal or unethical practices like plagiarism, forgery, and sabotage. Our experiment investigates the existence of such behavior in a setting where we pay subjects a flat wage to perform a repetitive task, and provide them with alternative leisure activities.

Interestingly, our data reveal that individuals work harder when they receive a feedback on their relative position in their group. This provides evidence that people care about their relative position, and that social comparisons increase motivation for work.

Another striking result of our experimental study is that some people are willing to incur a cost to artificially increase their relative position in their group without any expectation of monetary return of any sort, either by sabotaging the work of others or by increasing their own output artificially. In both redemption and sabotage treatments, individuals buy points when their performance is close to that of others, either to reach the highest rank or to avoid the lowest one. The sabotage treatment provides clear evidence that some people are willing to engage in wasteful status-seeking activities.

Overall, we find support for our behavioral theoretical predictions, as there is significantly higher performance in the ranking treatment than in the baseline treatment, and significantly higher performance in the ranking than in the sabotage treatment. Introducing the 
opportunity to increase artificially one's own relative performance in the redemption treatment does not lead to an improvement in average performance.

We also find some evidence of an in-group bias and bonding. Indeed, when people are matched with peers from the same school, they are more likely to increase their own performance artificially by buying redemption points, but they are less likely to sabotage their group members. Group identity seems to favor positive rivalry but it discourages destructive competition among peers.

Our interpretation is that competitive preferences and a desire for dominance (Rustichini, 2008) help to explain why people care so much about their relative position that they are willing to pay to improve it. Our intuition is that paying people a flat wage leads those individuals who have competitive preferences to express them through status-seeking activities, including sabotaging the work of others.

An objection to these interpretations of the data could be that effort choices simply derive from the fact that participants feel committed to perform the task in order to please the experimenter perceived as an 'authority' (see Zizzo, 2010 for an analysis of experimenter demand effects). Although we acknowledge that such effects may exist, we think that this interpretation is unlikely to account for our results for several reasons. First, we were careful to avoid having our own students in the experiment, to use no frame in the instructions, and to minimize the interactions between the subjects and the experimenter. ${ }^{16}$ Second, even if some form of authority relationship between the participants and the experimenter did still exist, this would mirror the field setting where such a vertical relationship exists, enhancing the external

\footnotetext{
${ }^{16}$ A debriefing written questionnaire asking subjects to describe their choice and strategy did not show any evidence for such an experimenter demand effect.
} 
validity of our experiment. Finally, a demand effect cannot explain the differences observed across treatments. Recall that our main aim was not to identify the determinants of performance in the baseline treatment but to investigate the effects of feedback on relative performance. As such, we believe that our interpretations are the most consistent with all of our findings.

A natural extension is to investigate whether using a competitive payment scheme would reduce or increase this costly status-seeking behavior by focusing competitive behavior on increasing earnings.

\section{REFERENCES}

Abbink, K., D. Masclet, and M. van Veelen (2009), "Reference Point Effects in Antisocial Preferences," SSRN_id1468567.pdf.

Abbink, K. and A. Sadrieh (2009), "The Pleasure of Being Nasty," Economics Letters, 105(3), 306-308.

Akerlof, G. and R. Kranton (2000), "Economics and Identity," Quarterly Journal of Economics, 115(3), 715-753.

Allgood, S. (2006), "The Marginal Costs and Benefits of Redistributing Income and the Willingness to Pay for Status," Journal of Public Economic Theory, 8(3), 357-377.

Anderson, C. and L. Putterman (2006), "Do Non-Strategic Sanctions Obey the Law of Demand? The Demand for Punishment in the Voluntary Contribution Mechanism." Games and Economic Behavior, 54(1), 1-24.

Azmat, G. and N. Iriberri (2010a), "The Importance of Relative Performance Feedback Information: Evidence from a Natural Experiment using High-school Students," forthcoming in Journal of Public Economics.

_. (2010b), "The Provision of Relative Performance Feedback Information: An Experimental Analysis of Performance and Happiness," Mimeo, Universitat Pompeu Fabra.

Ball, S. and C. Eckel (1996), "Buying Status: Experimental Evidence on Status in Negotiation," Psychology and Marketing, 13, 381-405.

Ball, S. and C. Eckel (1998), "The Economic Value of Status." Journal of Socio-Economics 24(4), 495-514.

Ball, S., C. Eckel, P. Grossman, and W. Zame (2001), "Status in Markets," Quarterly Journal of Economics, 116(1), 161-188.

Baron, J. (1988), "The Employment Relation as a Social Relation." Journal of the Japanese and International Economy, 2(4), pp. 492- 525. 
Berry, C., D. Ones, and P. Sackett (2007), "Interpersonal Deviance, Organizational Deviance, and Their Common Correlates: A Review and Meta-Analysis," Journal of Applied Psychology 92, 410-424.

Blanes i Vidal, J. and M. Nossol (2009), "Tournaments without Prizes: Evidence from Personnel Records," Mimeo, London School of Economics.

Brewer, M. (1999), "The Psychology of Prejudice: Ingroup Love and Outgroup Hate?," Journal of Social Issues, 55(3), 429-435.

Brown, G., J. Gardner, A. Oswald, and J. Qian (2008), "Does Wage Rank Affect Employees' Wellbeing?," Industrial Relations, 47(3), 355-389.

Carpenter, J., P. Matthews and J. Schirm (2010), "Tournaments and Office Politics: Evidence from a real effort experiment" American Economic Review, 100(1), 504-17.

Charness, G. and B. Grosskopf (2001), "Relative Payoffs and Happiness," Journal of Economic Behavior and Organization, 45(3), 301-328.

Charness, G. and P. Kuhn (2007), "Does pay inequality affect worker effort? Experimental evidence," Journal of Labor Economics, 25(4), 693-723.

Charness G. and M. Rabin (2002), "Understanding Social Preferences with Simple Tests," Quarterly Journal of Economics, 117(3), 817-869.

Charness, G., L. Rigotti, and A. Rustichini (2007), "Individual Behavior and Group

Membership," American Economic Review, 97(4), 1340-1352.

Chen, K. (2003). "Sabotage in Promotion Tournaments," Journal of Law, Economics, and Organization, 19(1), 119-139.

Chen, Y. and X. Li (2009),."Group identity and social preferences," American Economic Review, 99(1), 431-457.

Clark, A., P. Frijters, and M. Shields (2008), "Relative Income, Happiness and Utility: An Explanation for the Easterlin Paradox and Other Puzzles," Journal of Economic Literature, 46(1), 95-145.

Clark, A. and A. Oswald (1996), "Satisfaction and Comparison Income," Journal of Public Economics, 61, 359-81.

Clark, A., D. Masclet, and M. C. Villeval (2010), "Effort and Comparison Income: Experimental and Survey Evidence," Industrial and Labor Relations Review, 63(3), 407426.

Cohn A., E. Fehr and L. Goette (2009) “ Fairness and Effort - Evidence from a Field Experiment, working paper.

Dickinson D. (1999), "An Experimental Examination of Labor Supply and Work Intensities," Journal of Labor Economics, 17(4), 638-670.

Dohmen T. and A. Falk (2010). Performance Pay and Multi-dimensional Sorting Productivity, Preferences and Gender, forthcoming in American Economic Review.

Duflo, E. and E. Saez (2002), "Participation and Investment Decision in a Retirement Plan: The Influence of Colleagues' Choices," Journal of Public Economics, 85, 121-48.

Duesenberry, J. (1949), Income, saving and the theory of consumer behavior, Cambridge MA : Harvard University Press.

Eckel C., E. Fatas, and R. Wilson (2009), "Status and Cooperation in Organizations," University of Texas at Dallas and Rice University. 
Eckel, C. and R. Wilson (2007), "Social Learning in Coordination Games: Does Status Matter?," Experimental Economics, 10(3), 317-330.

Ellingsen, T. and M. Johannesson (2008), "Pride and Prejudice: The Human Side of Incentive Theory," American Economic Review, 98, 990-1008.

Eriksson, T., A. Poulsen, and M.C. Villeval (2009), "Feedback and Incentives: Experimental Evidence," Labour Economics, 16, 679-688.

Falk A., E. Fehr E., and U. Fischbacher (2005), "Driving forces behind informal sanctions," Econometrica, 73(6), 2017-2030.

Falk, A. and A. Ichino (2006) "Clean Evidence on Peer Pressure", Journal of Labor Economics, 24 (1), 39-57.

Falk, A., E. Fehr and D. Huffman. (2008). "The Power and Limits of Tournament Incentives." Discussion Paper University of Zurich.

Fehr, E., S. Gächter, and G. Kirchsteiger (1997), "Reciprocity as a Contract Enforcement Device: Experimental Evidence." Econometrica, Vol.65, No.4, pp. 833-60.

Fehr, E., G. Kirchsteiger, and A. Riedl, (1993), "Does Fairness Prevent Market Clearing? An Experimental Investigation." Quarterly Journal of Economics, Vol.108, pp. 437-59.

Fehr, E. and K. Schmidt (1999), "A Theory of Fairness, Competition and Cooperation." Quarterly Journal of Economics, 114(3), 817-868.

Ferrer-i-Carbonell, A. (2005), "Income and Well-Being: An Empirical Analysis of the Comparison Income Effect," Journal of Public Economics, 89, 997-1019.

Frank, R. (1985), "The Demand for Unobservable and Other Nonpositional Goods," American Economic Review, 75(1), 101-116. , (1988), Passions without Reason. New-York: Norton.

Garicano, L. and Palacios-Huerta, I. (2006), "Sabotage in tournaments: making the beautiful game a little less beautiful", mimeo.

Gächter, S. and C. Thoeni (2009), "Social Comparisons and Performance: Experimental Evidence on the Fair-Wage Effort Hypothesis." CEDEX Discussion Paper 2209-23.

Glaeser, E., B. Sacerdote and J. Scheinkman (1996), "Crime and Social Interactions." Quarterly Journal of Economics 111(2), 507-48.

Gneezy, U. and A. Rustichini (2000), "Pay Enough or Don't Pay at All," Quarterly Journal of Economics, 115(3), 791-810.

Gneezy U. and J. A. List (2006) "Putting Behavioral Economics to Work : testing for Gift Exchange in Labor Markets using Field Experiments", Econometrica, Vol. 74, No. 5, pp.1365-1384.

Goette, L. and D. Huffman (2006), "Incentives and the Allocation of Effort Over Time: The Joint Role of Affective and Cognitive Decision Making," IZA Discussion Papers 2400, Bonn.

Greiner, B. (2004), "An online recruitment system for economic experiments," In Forschung und wissenschaftliches Rechnen GWDG Bericht 63, Ed. K. Kremer, and V. Macho, Göttingen: Gesellschaft fur Wissenschaftliche Datenverarbeitung. 
Greiner B., A. Ockenfels and P. Werner, (2010) "Wage Transparency and Performance: A Real-Effort Experiment, Working Paper Series in Economics 48, University of Cologne, Department of Economics.

Halevy, N., G. Bornstein and L. Sagiv (2008), "'InGroup Love' and 'Outgroup Hate' as Motives for Individual Participation in Intergroup Conflicts: A New game Paradigm," Psychological Science, 19(4), 405-411.

Hannan, R. L., R. Krishnan and D. Newman (2008) "The Effects of disseminating Relative Performance Feedback in Tournament Versus Individual Performance Compensation Plans", The Accounting Review, 83-4.

Harbring, C., B. Irlenbusch, M. Kräckel, and R. Selten (2007), "Sabotage in Asymmetric Contests - An Experimental Analysis," International Journal of the Economics and Business, 14, 201-223.

Harbring, C., Irlenbusch, B., (2008) "How many winners are good to have? On tournaments with sabotage," Journal of Economic Behavior and Organization, 65, 682-702.

Hopkins, E. and T. Kornienko (2009), "Status, Affluence, and inequality: Rank-based comparisons in games of status," Games and Economic Behavior, 67(2), 552-568.

Huberman, B., C. Loch, and A. Önçüler (2004), "Status as a Valued Resource," Social Psychology Quarterly, 67(1), 103-114.

James H., "Why Did You Do That? An Economic Examination of the Effect of Extrinsic Compensation on Intrinsic Motivation and Performance," Journal of Economic Psychology, 26(4), 2005, 549-566.

Konrad, K. (2000): Sabotage in Rent-seeking Contests, Journal of Law, Economics and Organization 16(1), 155-165.

Kreps, D. (1997), "Intrinsic Motivation and Extrinsic Incentives," American Economic Review, 87(2), 359-364.

Kube, S., A. Marechal, and C. Puppe (2008), "Do Wage Cuts damage Work Morale Evidence from a Natural Field Experiment", IEW Working Paper.

Kuhnen C. and A. Tymula (2008), "Rank Expectations, Feedback and Social Hierarchies working paper.

Kumru, C. and L. Vesterlund (2008), "The Effects of Status on Voluntary Contribution." Working Papers 266, University of Pittsburgh, Department of Economics.

Lazear, E. (1989), "Pay equality and industrial politics," Journal of Political Economy, 97(3), 561-580.

Luttmer, E. (2005), "Neighbors as Negatives: Relative Earnings and Well-Being," Quarterly Journal of Economics, 120(3), 963-1002.

Masclet, D. and M. C. Villeval (2008), "Punishment, inequality, and welfare: a public good experiment," Social Choice and Welfare, 31(3), 475-502.

Prendergast, C. (1999), "The Provision of Incentives in Firms," Journal of Economic Literature, 37(1), 7-63.

Preston, I., and S. Szymanski (2003), "Cheating in Contests," Oxford Review of Economic Policy, 19(4), 612-624.

Rege, M. (2008), "Why do people care about social status?" Journal of Economic Behavior and Organization 66, 233-242. 
Rustichini, A. (2008), "Dominance and Competition," Journal of the European Economic Association, 6(2-3), 647-656.

Rustichini, A. and A. Vostroknutov (2008), "Competition with Skill and Luck," Mimeo, University of Minnesota.

Schwieren, C. and D. Weichselbaumer (2010), "Does competition enhance performance or cheating? A laboratory experiment," Journal of Economic Psychology, 31 (3), 241-253.

Shleifer, A. (2004), "Does Competition Destroy Ethical Behavior?," American Economic Review Papers and Proceedings, 94(2), 414-418.

Tajfel, H., C. Flament, M. Billig, and R. Bundy (1971), "Social categorization and intergroup behavior," European Journal of Social Psychology, 1, 147-175.

Tziner, A., S. Goldberg, and R. Or (2006), "Counterproductive Behavior at Work and Some Individual Characteristics," Journal of Academy of Business and Economics, 6, 128-139.

Veblen, T. (1949), The Theory of the Leisure Class, George Allen and Unwin, London, Originally published 1899 by Macmillan, New York.

Young, S. M., Fisher, J. and T. M. Lindquist (1993) "The effect of intergroup competition and intragroup cooperation on slack and output in a manufacturing setting", The Accounting Review 68 (3), 466-483.

Zizzo D. (2010) "Experimenter demand effects in economic experiments" Experimental Economics, 13, 75-98. 
Table 1. Characteristics of the experimental sessions

\begin{tabular}{ccccc}
\hline $\begin{array}{c}\text { Session } \\
\text { number }\end{array}$ & $\begin{array}{c}\text { Number of } \\
\text { subjects }\end{array}$ & $\begin{array}{c}\text { Number of } \\
\text { groups }\end{array}$ & Treatment & Location \\
\hline 1 & 15 & 5 & Baseline & Rennes \\
2 & 15 & 5 & Baseline & Rennes \\
3 & 15 & 5 & Baseline & Lyon \\
4 & 9 & 3 & Baseline & Lyon \\
5 & 15 & 5 & Ranking & Rennes \\
6 & 15 & 5 & Ranking & Rennes \\
7 & 15 & 5 & Ranking & Lyon \\
8 & 15 & 5 & Ranking & Lyon \\
9 & 12 & 4 & Sabotage & Rennes \\
10 & 15 & 5 & Sabotage & Rennes \\
11 & 15 & 5 & Sabotage & Rennes \\
12 & 15 & 5 & Sabotage & Lyon \\
13 & 15 & 5 & Sabotage & Lyon \\
14 & 15 & 5 & Redemption & Rennes \\
15 & 15 & 5 & Redemption & Lyon \\
16 & 15 & 5 & Redemption & Lyon \\
17 & 15 & 5 & Redemption & Lyon \\
18 & 15 & 5 & Redemption & Lyon \\
19 & 15 & 5 & Ranking & Rennes \\
20 & 15 & 5 & Ranking & Rennes \\
21 & 15 & 5 & Ranking & Rennes \\
22 & 15 & 5 & Ranking & Rennes \\
23 & 12 & 4 & Ranking & Lyon \\
24 & 12 & 4 & Ranking & Lyon \\
\hline
\end{tabular}

${ }^{\neq}$: ranking treatment without symbol 
Table 2. Average performance by session in each treatment

\begin{tabular}{ccccccc}
\hline Baseline & Ranking & Ranking & $\begin{array}{c}\text { Sabotage } \\
\text { First stage }\end{array}$ & $\begin{array}{c}\text { Sabotage } \\
\text { Final }\end{array}$ & $\begin{array}{c}\text { Redemption } \\
\text { First stage }\end{array}$ & $\begin{array}{c}\text { Redemption } \\
\text { Final }\end{array}$ \\
\hline 23.54 & 27.51 & 27.91 & 27.00 & 25.55 & 29.56 & 30.95 \\
$(11.60)$ & $(8.41)$ & $(9.41)$ & $(6.17)$ & $(7.28)$ & $(5.73)$ & $(5.82)$ \\
22.19 & 30.08 & $26.9^{\mp}$ & 25.21 & 23.87 & 24.26 & 25.04 \\
$(9.98)$ & $(8.13)$ & $(9.06)$ & $(12.03)$ & $(11.86)$ & $(8.46)$ & $(9.06)$ \\
22.6 & 29.96 & $21.65^{\mp}$ & 27.52 & 26.54 & 27.43 & 28.82 \\
$(11.81)$ & $(5.36)$ & $(11.28)$ & $(7.30)$ & $(7.11)$ & $(7.56)$ & $(8.10)$ \\
25.04 & 30.28 & $27.12^{\neq}$ & 18.66 & 18.08 & 25.34 & 25.58 \\
$(12.12)$ & $(7.42)$ & $(7.47)$ & $(14.57)$ & $(14.22)$ & $(11.33)$ & $(11.47)$ \\
& 26.67 & $28.44^{\neq}$ & 23.13 & 22.13 & 22.72 & 22.82 \\
& $(8.72)$ & $(4.71)$ & $(13.21)$ & $(12.93)$ & $(13.10)$ & $(13.15)$ \\
\hline 23.15 & $\ldots$ & 27.65 & 24.19 & 23.13 & 25.86 & 26.64 \\
$(11.35)$ & & $(8.00)$ & $(11.76)$ & $(11.51)$ & $(9.89)$ & $(10.26)$ \\
\hline
\end{tabular}

Note: Numbers in parentheses are standard deviations. ${ }^{\neq}$: Variant of the ranking treatment with symbols 
Table 3. Determinants of effort

\begin{tabular}{|c|c|c|c|c|}
\hline $\begin{array}{l}\text { Dependent variable } \\
\text { Models }\end{array}$ & $\begin{array}{c}\text { Initial perf. } \\
R E G L S^{a} \\
\text { (1) }\end{array}$ & $\begin{array}{l}\text { Initial perf. } \\
R E G L S^{a} \\
\text { (2) }\end{array}$ & $\begin{array}{l}\text { Initial perf. } \\
\text { RE Tobit } \\
\text { (3) }\end{array}$ & $\begin{array}{l}\text { Initial perf. } \\
\text { RE Tobit } \\
\text { (4) }\end{array}$ \\
\hline Baseline & Ref. & Ref. & Ref. & Ref. \\
\hline Ranking & $\begin{array}{l}4.512 * * * \\
(0.924)\end{array}$ & $\begin{array}{l}4.528 * * * \\
(1.0280)\end{array}$ & $\begin{array}{l}4.780 * * * \\
(1.467)\end{array}$ & $\begin{array}{c}3.310 * * \\
(1.495)\end{array}$ \\
\hline Sabotage & $\begin{array}{c}1.038 \\
(1.560)\end{array}$ & $\begin{array}{c}1.144 \\
(1.298)\end{array}$ & $\begin{array}{c}1.116 \\
(1.663)\end{array}$ & $\begin{array}{l}0.5288 \\
(1.694)\end{array}$ \\
\hline Redemption & $\begin{array}{l}2.711 * * \\
(1.192)\end{array}$ & $\begin{array}{c}2.923 * * \\
(1.143)\end{array}$ & $\begin{array}{l}3.012 * \\
(1.652)\end{array}$ & $\begin{array}{c}1.460 \\
(1.683)\end{array}$ \\
\hline \multicolumn{4}{|c|}{ Ranking* periods 6-10 } & $\begin{array}{c}2.960 * * * \\
(0.578)\end{array}$ \\
\hline \multicolumn{4}{|c|}{ Sabotage* periods 6-10 } & $\begin{array}{l}1.188^{*} \\
(0.654)\end{array}$ \\
\hline \multicolumn{4}{|c|}{ Redemption* periods 6-10 } & $\begin{array}{c}3.126 * * * \\
(0.647)\end{array}$ \\
\hline Periods 6-10 & $\begin{array}{c}0.558 \\
(0.431)\end{array}$ & $\begin{array}{l}0.558 \\
(0.431)\end{array}$ & $\begin{array}{c}0.459^{* *} \\
(0.240)\end{array}$ & $\begin{array}{c}-1.711 * * * \\
(0.495)\end{array}$ \\
\hline Demographics & no & yes & yes & yes \\
\hline Constant & $\begin{array}{c}22.878 * * * \\
(0.535)\end{array}$ & $\begin{array}{c}21.693 * * * \\
(0.872)\end{array}$ & $\begin{array}{c}21.420 * * * \\
(1.545)\end{array}$ & $\begin{array}{c}22.496 * * * \\
(1.562)\end{array}$ \\
\hline Observations & 3450 & 3450 & 3450 & 3450 \\
\hline Left-censored obs. & - & - & 178 & 178 \\
\hline Log likelihood & - & - & -11034.217 & -11015.973 \\
\hline Wald $\chi^{2}$ & 4588.26 & 8293.61 & 26.51 & 63.24 \\
\hline$p>\chi^{2}$ & 0.000 & 0.000 & 0.000 & 0.000 \\
\hline
\end{tabular}

Notes: RE GLS ${ }^{\mathrm{a}}=$ Random Effects Generalized Least Squares; RE Tobit ${ }^{\mathrm{b}}=$ Random Effects Tobit. *** Significant at the 0.01 level; ** at the 0.05 level; * at the 0.1 level. Since observations within a session may be dependent, estimates are conducted with robust standard errors clustered on sessions. Robust standard errors are in parentheses. 
Table 4. Determinants of sabotage (random-effects Tobit models)

\begin{tabular}{|c|c|c|c|c|c|}
\hline \multirow{2}{*}{$\begin{array}{c}\text { Dependent variable } \\
\text { Models }\end{array}$} & \multicolumn{5}{|c|}{ Total number of points assigned by subject $i$ to subject $j$} \\
\hline & (1) & (2) & (3) & (4) & $(5)$ \\
\hline Actual performance & $\begin{array}{l}0.684 * * * \\
(0.201)\end{array}$ & $\begin{array}{c}0.630 * * * \\
(0.199)\end{array}$ & $\begin{array}{c}0.588 * * * \\
(0.199)\end{array}$ & $\begin{array}{c}0.573 * * * \\
(0.206)\end{array}$ & $\begin{array}{c}0.544 * * \\
(0.230)\end{array}$ \\
\hline Actual perf. Squared & $\begin{array}{l}-0.009 * * \\
(0.004)\end{array}$ & $\begin{array}{c}-0.008 * * \\
(0.004)\end{array}$ & $\begin{array}{l}-0.007^{*} \\
(0.004)\end{array}$ & $\begin{array}{l}-0.006^{*} \\
(0.004)\end{array}$ & $\begin{array}{l}-0.007 \\
(0.004)\end{array}$ \\
\hline $\operatorname{Rank}_{\mathrm{i}}$ & $\begin{array}{l}1.573 * * * \\
(0.510)\end{array}$ & & & & \\
\hline $\operatorname{Rank}_{\mathrm{i}}{ }^{1}$ & & Ref. & Ref. & Ref. & Ref. \\
\hline $\operatorname{Rank}_{\mathrm{i}}^{2}$ & & $\begin{array}{c}2.483 * * * \\
(0.746)\end{array}$ & $\begin{array}{c}2.504 * * * \\
(0.744)\end{array}$ & $\begin{array}{l}-0.076 \\
(0.913)\end{array}$ & $\begin{array}{c}0.334 \\
(0.928)\end{array}$ \\
\hline $\operatorname{Rank}_{\mathrm{i}}^{3}$ & & $\begin{array}{c}2.971 * * * \\
(1.028)\end{array}$ & $\begin{array}{c}2.877 * * * \\
(1.026)\end{array}$ & $\begin{array}{c}0.636 \\
(1.203)\end{array}$ & $\begin{array}{l}-0.451 \\
(1.412)\end{array}$ \\
\hline $\operatorname{Rank}_{\mathrm{i}}^{2} * \operatorname{Rank}_{\mathrm{j}}^{1}$ & & & & $\begin{array}{c}4.037 * * * \\
(0.821)\end{array}$ & \\
\hline $\operatorname{Rank}_{\mathrm{i}}^{3} * \operatorname{Rank}_{\mathrm{j}}^{2}$ & & & & $\begin{array}{c}3.145 * * * \\
(1.143)\end{array}$ & \\
\hline $\begin{array}{l}\text { Points of sabotage } \\
\text { received in }(t-1)\end{array}$ & & & & & $\begin{array}{c}0.160 \\
(0.102)\end{array}$ \\
\hline Positive difference & & & & & Ref. \\
\hline Equal performance & & & & & $\begin{array}{c}6.403 * * * \\
(1.278)\end{array}$ \\
\hline Negative difference & & & & & $\begin{array}{c}-0.034 \\
(0.100)\end{array}$ \\
\hline Low Negative difference & & & & & $\begin{array}{c}1.147 * * * \\
(0.313)\end{array}$ \\
\hline Periods 6-10 & $\begin{array}{l}-0637 \\
(0.580)\end{array}$ & $\begin{array}{c}-0.677 \\
(0.578)\end{array}$ & $\begin{array}{c}-0.697 \\
(0.575)\end{array}$ & $\begin{array}{c}-0.193 \\
(0.620)\end{array}$ & $\begin{array}{c}0.112 \\
(0.653)\end{array}$ \\
\hline Same gender & & & & $\begin{array}{c}0.443 \\
(0.643)\end{array}$ & $\begin{array}{c}0.363 \\
(0.714)\end{array}$ \\
\hline Same school & & & & $\begin{array}{c}-2.385 * * \\
(1.011)\end{array}$ & $\begin{array}{c}-3.161 * * * \\
(1.104)\end{array}$ \\
\hline Average medals ${ }_{-i}$ & & & & $\begin{array}{c}0.068 \\
(1.997)\end{array}$ & $\begin{array}{l}-0.232 \\
(2.541)\end{array}$ \\
\hline Average hats ${ }_{-i}$ & & & & $\begin{array}{c}-5.833 * * * \\
(1.974)\end{array}$ & $\begin{array}{c}-7.141 * * \\
(2.544)\end{array}$ \\
\hline Demographics & no & no & yes & yes & yes \\
\hline Constant & $\begin{array}{l}-16.467 * * * \\
(2.847) \\
\end{array}$ & $\begin{array}{c}-20.755^{* * * *} \\
(2.920) \\
\end{array}$ & $\begin{array}{c}-22.137 * * * \\
(3.039) \\
\end{array}$ & $\begin{array}{c}-21.205^{* * * *} \\
(3.203) \\
\end{array}$ & $\begin{array}{c}-21.898^{* * * *} \\
(3.604) \\
\end{array}$ \\
\hline Observations & 1440 & 1440 & 1440 & 1440 & 1440 \\
\hline Left-censored obs. & 1232 & 1232 & 1232 & 1232 & 1232 \\
\hline Log likelihood & -959.092 & -957.661 & -954.703 & -931.046 & -822.414 \\
\hline Wald $\chi^{2}$ & 24.51 & 27.98 & 33.27 & 69.28 & 71.17 \\
\hline$p>\chi^{2}$ & 0.000 & 0.000 & 0.000 & 0.000 & 0.000 \\
\hline
\end{tabular}

Notes: *** Significant at the 0.01 level; ** at the 0.05 level; * at the 0.1 level. Standard errors are in parentheses. 
Table 5. Determinants of the purchase of redemption points (random-effects Tobit models)

\begin{tabular}{|c|c|c|c|c|}
\hline \multicolumn{5}{|c|}{ Dependent Variable: Number of redemption points purchased by $i$} \\
\hline Models & $(1)$ & $(2)$ & (3) & (4) \\
\hline Actual performance & $\begin{array}{c}0.826 * * * \\
(0.303)\end{array}$ & $\begin{array}{c}0.797 * * * \\
(0.304)\end{array}$ & $\begin{array}{c}0.740 * * \\
(0.309)\end{array}$ & $\begin{array}{l}0.588^{*} \\
(0.345)\end{array}$ \\
\hline Actual performance & $-0.018 * * *$ & $-0.018 * * *$ & $-0.017 * *$ & $-0.015^{* *}$ \\
\hline Squared & $(0.006)$ & $(0.006)$ & $(0.007)$ & $(0.007)$ \\
\hline Rank $_{\mathrm{i}}$ & $\begin{array}{c}1.917 * * \\
(0.768)\end{array}$ & & & \\
\hline $\operatorname{Rank}_{\mathrm{i}}^{1}$ & Ref. & Ref. & Ref. & Ref. \\
\hline $\operatorname{Rank}_{\mathrm{i}}^{2}$ & & $\begin{array}{c}2.442 * * \\
(1.137)\end{array}$ & $\begin{array}{l}2.058^{*} \\
(1.149)\end{array}$ & $\begin{array}{c}1.456 \\
(1.345)\end{array}$ \\
\hline $\operatorname{Rank}_{\mathrm{i}}^{3}$ & & $\begin{array}{c}3.750 * * \\
(1.543)\end{array}$ & $\begin{array}{l}2.892^{*} \\
(1.611)\end{array}$ & $\begin{array}{l}2.928^{*} \\
(1.627)\end{array}$ \\
\hline Positive difference & & & & Ref. \\
\hline Equal performance & & & & $\begin{array}{l}2.469 * \\
(1.468)\end{array}$ \\
\hline Negative difference & & & & $\begin{array}{c}-0.138 \\
(0.167)\end{array}$ \\
\hline Periods 6-10 & $\begin{array}{c}-3.044 * * * \\
(0.946)\end{array}$ & $\begin{array}{c}-3.053 * * * \\
(0.944)\end{array}$ & $\begin{array}{c}-2.654 * * * \\
(0.964)\end{array}$ & $\begin{array}{c}-2.606 * * * \\
(0.970)\end{array}$ \\
\hline Same school & & & $\begin{array}{c}3.637 * * * \\
(1.398)\end{array}$ & $\begin{array}{c}3.901 * * * \\
(1419)\end{array}$ \\
\hline Same gender & & & $\begin{array}{c}1.236 \\
(0.968)\end{array}$ & $\begin{array}{l}1.191 \\
(0.973)\end{array}$ \\
\hline Average medals $_{-i}$ & & & $\begin{array}{c}0.543 \\
(2.947)\end{array}$ & $\begin{array}{c}1552 \\
(3.075)\end{array}$ \\
\hline Average hats-I & & & $\begin{array}{l}-4.446 \\
(2.744)\end{array}$ & $\begin{array}{l}-3.869 \\
(2.763)\end{array}$ \\
\hline Demographics & no & no & yes & Yes \\
\hline Constant & $\begin{array}{c}-13.927 * * * \\
(4.067) \\
\end{array}$ & $\begin{array}{c}-19.494 * * * \\
(4.358) \\
\end{array}$ & $\begin{array}{c}-21.592 * * * \\
(5.023) \\
\end{array}$ & $\begin{array}{c}-18.893 * * \\
(5.687) \\
\end{array}$ \\
\hline Observ & 750 & 750 & 750 & 750 \\
\hline Left-censored obs. & 636 & 636 & 636 & 636 \\
\hline Log likelihood & -521.240 & -521.041 & -509.297 & -507.138 \\
\hline Wald $\chi^{2}$ & 32.80 & 33.17 & 48.70 & 51.28 \\
\hline$p>\chi^{2}$ & 0.000 & 0.000 & 0.000 & 0.000 \\
\hline
\end{tabular}

Notes: *** Significant at the 0.01 level; ** at the 0.05 level; * at the 0.1 level. Standard errors are in parentheses. 
Table 6. First differences in work effort by treatment (Random-Effects GLS models)

\begin{tabular}{|c|c|c|c|c|c|c|}
\hline $\begin{array}{l}\text { Treatments } \\
\text { Models }\end{array}$ & $\begin{array}{c}\text { Ranking } \\
\text { (1) }\end{array}$ & $\begin{array}{c}\text { Sabotage } \\
(2)\end{array}$ & $\begin{array}{c}\text { Redemption } \\
\text { (3) }\end{array}$ & $\begin{array}{c}\text { Ranking } \\
\text { (4) }\end{array}$ & $\begin{array}{c}\text { Sabotage } \\
\text { (5) }\end{array}$ & $\begin{array}{c}\text { Redemption } \\
\text { (6) }\end{array}$ \\
\hline $\operatorname{Rank}_{\mathrm{i}}$ in $(t-1)$ & $\begin{array}{c}1.047 * * * \\
(0.134)\end{array}$ & $\begin{array}{c}1.137 * * * \\
(0.251)\end{array}$ & $\begin{array}{c}1.447 * * * \\
(0.339)\end{array}$ & & & \\
\hline $\operatorname{Rank}_{\mathrm{i}}{ }^{1}$ in $(t-1)$ & & & & Ref. & Ref. & Ref. \\
\hline $\operatorname{Rank}_{\mathrm{i}}^{2}$ in $(t-1)$ & & & & $\begin{array}{c}471 \\
(0.354)\end{array}$ & $\begin{array}{c}0.579 \\
(0.590)\end{array}$ & $\begin{array}{c}1.731 * * * \\
(0.576)\end{array}$ \\
\hline $\operatorname{Rank}_{\mathrm{i}}^{3}$ in $(t-1)$ & & & & $\begin{array}{l}1.157 * * * \\
(0.247)\end{array}$ & $\begin{array}{c}1.951 * * * \\
(0.565)\end{array}$ & $\begin{array}{c}3.195 * * * \\
(0.591)\end{array}$ \\
\hline $\begin{array}{l}\operatorname{Rank}_{\mathrm{i}}^{3} \text { in }(t-1)^{*} \\
\text { Change }\end{array}$ & & & & & $\begin{array}{c}3.283 \\
(2.883)\end{array}$ & $\begin{array}{c}-2.292 * * * \\
(0.486)\end{array}$ \\
\hline $\begin{array}{l}\text { Points of sabotage } \\
\text { received in }(t-1)\end{array}$ & & $\begin{array}{c}-0.239 * * \\
(0.105)\end{array}$ & & & $\begin{array}{c}-0.321 * * \\
(0.142)\end{array}$ & \\
\hline $\begin{array}{l}\text { Points of sabotage } \\
\text { assigned in }(t-1)\end{array}$ & & $\begin{array}{c}0.137 * * * \\
(0.032)\end{array}$ & & & $\begin{array}{c}0.140 * * * \\
(0.024)\end{array}$ & \\
\hline $\begin{array}{l}\text { Points of redemption } \\
\text { purchased in }(t-1)\end{array}$ & & & $\begin{array}{c}0.304 * * * \\
(0.071)\end{array}$ & & & $\begin{array}{c}0.309 * * * \\
(0.079)\end{array}$ \\
\hline Constant & $\begin{array}{l}-1.611 * * * \\
(0.250)\end{array}$ & $\begin{array}{l}-1.837 * * * \\
(0.511)\end{array}$ & $\begin{array}{c}-2.518 * * * \\
(0.723)\end{array}$ & $\begin{array}{l}268^{*} \\
(0.162)\end{array}$ & $\begin{array}{l}-0.474 \\
(0.380)\end{array}$ & $\begin{array}{c}-1.182 * * \\
(0.514)\end{array}$ \\
\hline Observations & 1296 & 648 & 675 & 1296 & 648 & 675 \\
\hline Wald $\chi^{2}$ & 71.00 & 371.08 & 53.22 & 199.85 & & 177.16 \\
\hline$p>\chi^{2^{n}}$ & 0.000 & 0.000 & 0.000 & 0.000 & 0.000 & 0.000 \\
\hline
\end{tabular}

Notes: *** Significant at the 0.01 level; ** at the 0.05 level; * at the 0.1 level.

Robust standard errors are in parentheses, clustered at the session level. 


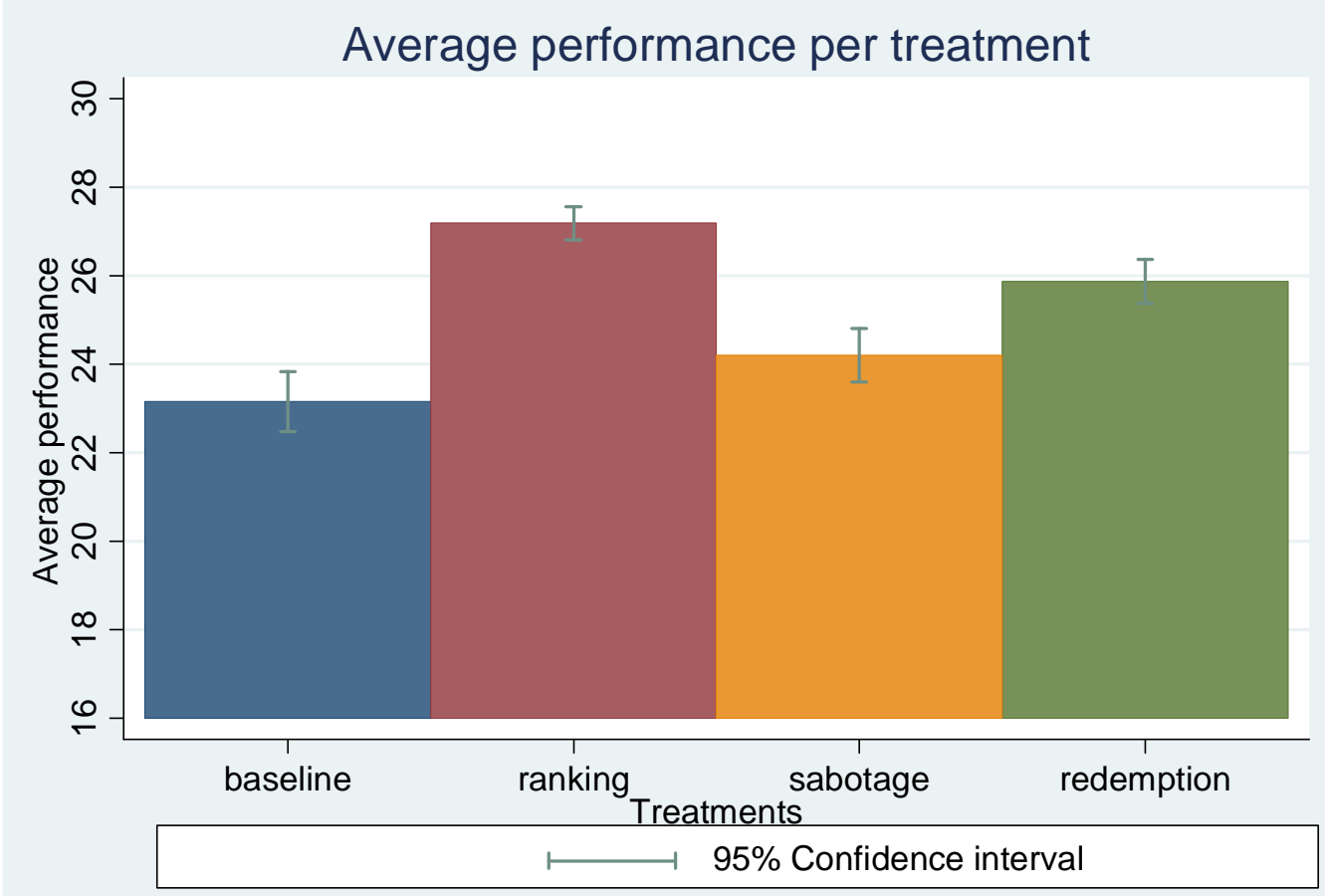

Fig.1. Average workers' initial performance by treatment

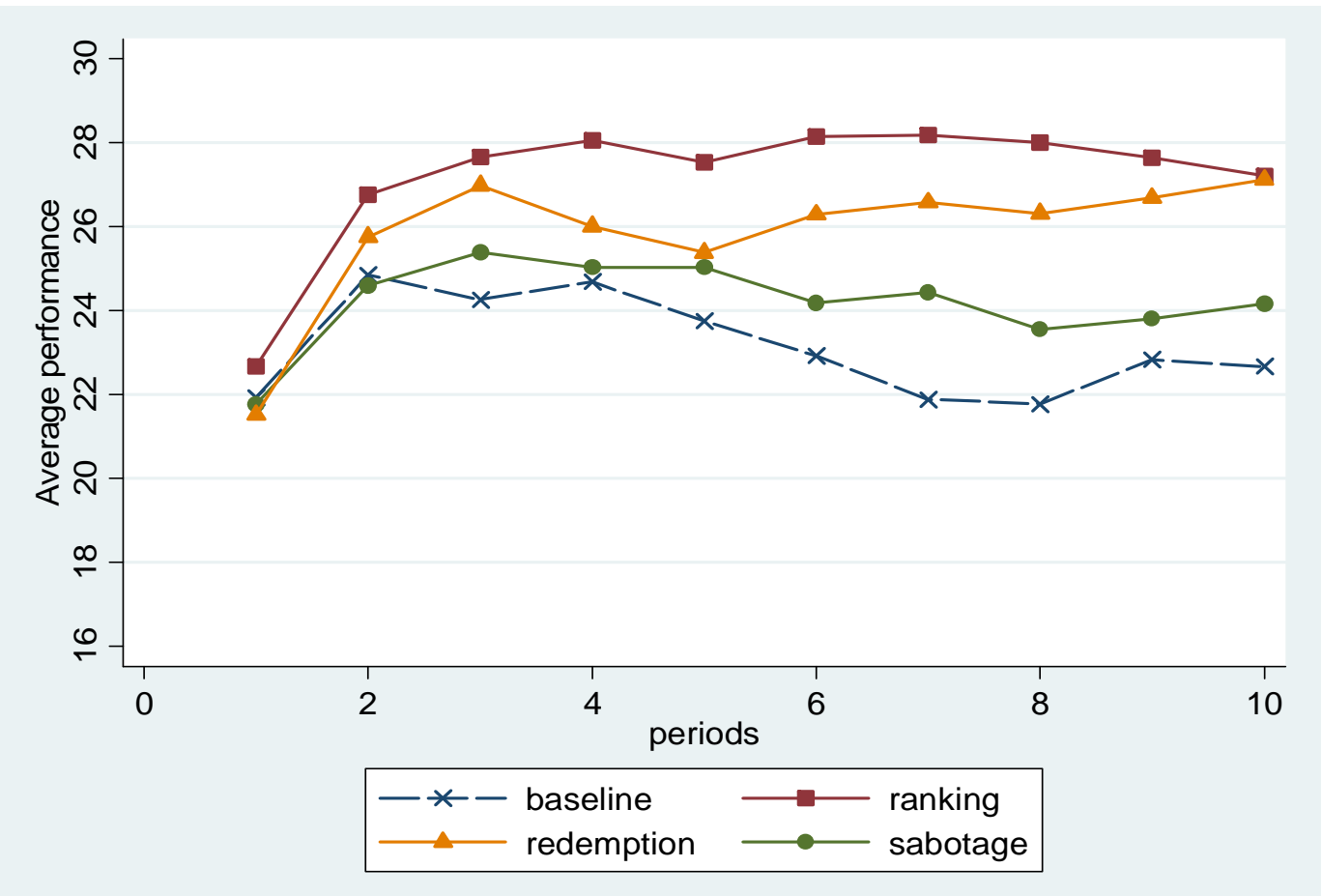

Fig.2. Evolution of the average performance over time by treatment 


\section{APPENDIX : Instructions}

\section{Instructions for the sabotage treatment}

The instructions for the other treatments are available from the authors upon request.

We thank you for participating in this experiment in economics during which you can earn money. You will receive a show-up fee of 5 Euros. In addition, you will receive additional earnings to perform a task. These earnings are given in ECU (experimental currency units). The conversion rate is:

$$
10 \mathrm{ECU}=1 \text { Euro }
$$

At the end of the session, your earnings in ECU will be added, converted into Euros and added to your show-up fee. The total amount of your payoff will be paid to you in private.

This session consists of 10 rounds that will start as soon as you have answered to some preliminary questions on your gender and your school. The successive parts start automatically. At the beginning of each part, all the participants are randomly matched in groups of three. Groups are rematched automatically at each new part. The identity of these co-participants will remain unknown.

\section{Description of each part}

At the beginning of each part, you receive 10 ECU to perform a task. This payoff is independent of your performance at the task.

Each part consists of two stages: in the first stage, you perform a task, then you are informed on your score and the scores of your two other group members; in the second stage, you can modify the score of your group members.

\section{Description of the first stage}

\section{The task}

The task consists of converting letters into numbers during two minutes. Your screen displays a table with two columns. The first column indicates letters and the second column indicates their correspondence in numbers. You are given a letter and you must enter the corresponding number in the box on your screen. You must validate your answer by pressing the 'OK' button.

Once you have validated your answer, you are immediately informed whether your answer is correct or not. If your answer is incorrect, you must enter a new number until the answer is correct. A new letter appears only after you have submitted a correct answer for the current letter.

As soon you have validated a correct answer, the conversion table of letters and numbers is modified and a new letter to convert is displayed on your screen. You can convert as many letters as you like during the two-minute period of time.

\section{Information on your screen at the beginning of a part}

At the very beginning of the first part, a table indicates for each group member his attributes in terms of gender and school.

During each part, you are continuously informed of the remaining time until the end of the part (at the top right of the screenshot: 'remaining time') and of your score (the number of correct answers).

Please find below a copy of the screenshot that will be displayed. 


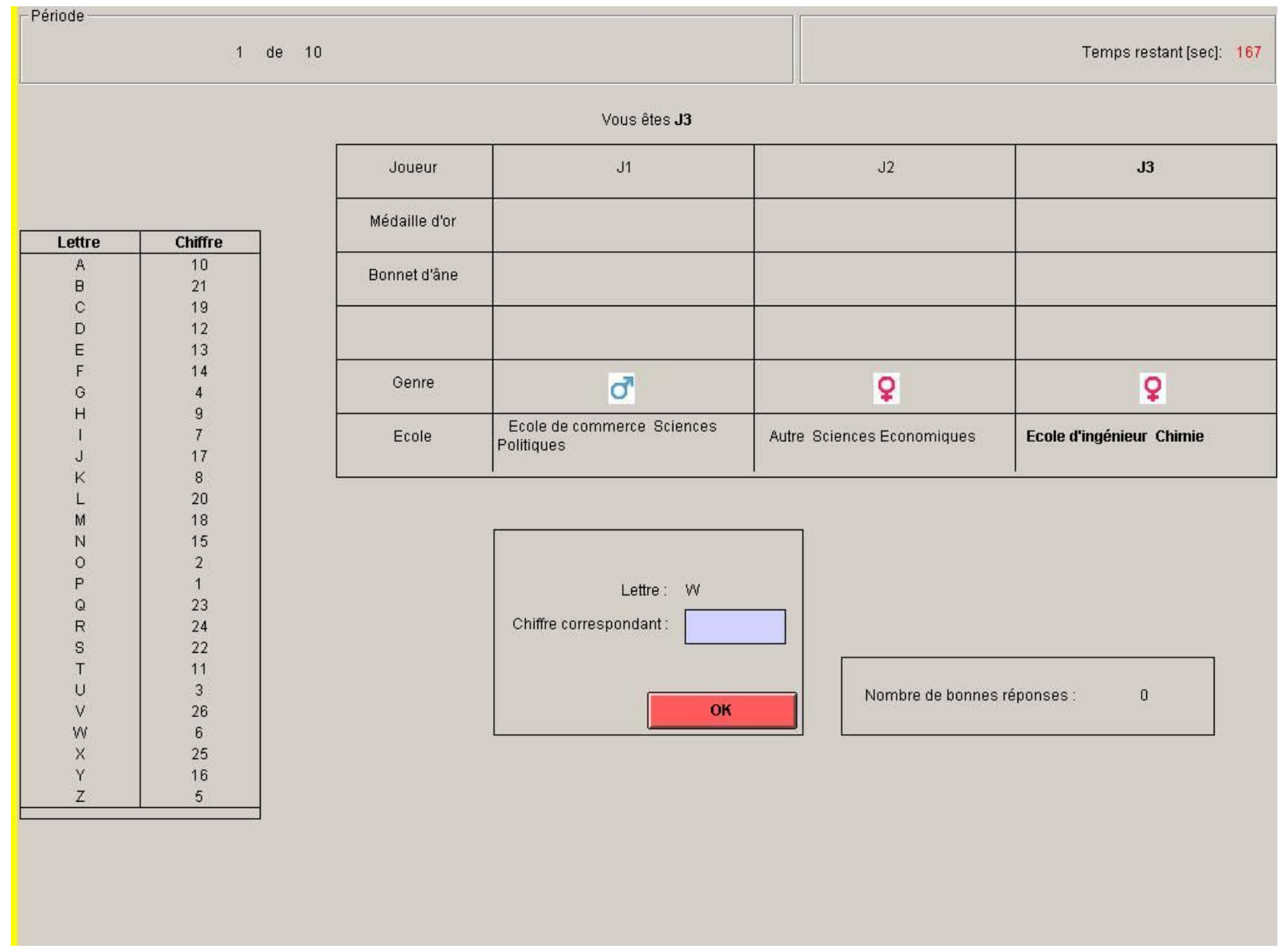

\section{Information on your screen at the end of the first stage}

After the two minutes have elapsed, a graph represents your score and the scores of your two group members as bars which height is proportional to the number of correct answers provided.

\section{Description of the second stage}

During the second stage, you can modify the score of each of the other group members. You can reduce the score of each of your group members in the limit of 20 units each. You cannot increase their score.

To modify the score of another member, you can use a slider as indicated on the figure below. By moving this scrollbar, you decide on the number of points that will reduce the scores of the other group members. Each point reduces the score by one unit. While moving the slider, you can see on the figure the score of the group member and the height of his bar decreasing. Since there are two other members in your group, you have two sliders.

Next, you must validate your choice by pressing the 'validate' button. If you modify the score of another group member, it costs you $0.5 \mathrm{ECU}$ for each unit reduced.

Similarly, your group members can modify your score by during the second stage. You ignore who has modified your score, if any.

Please find below a copy of the screenshot that will be displayed. 


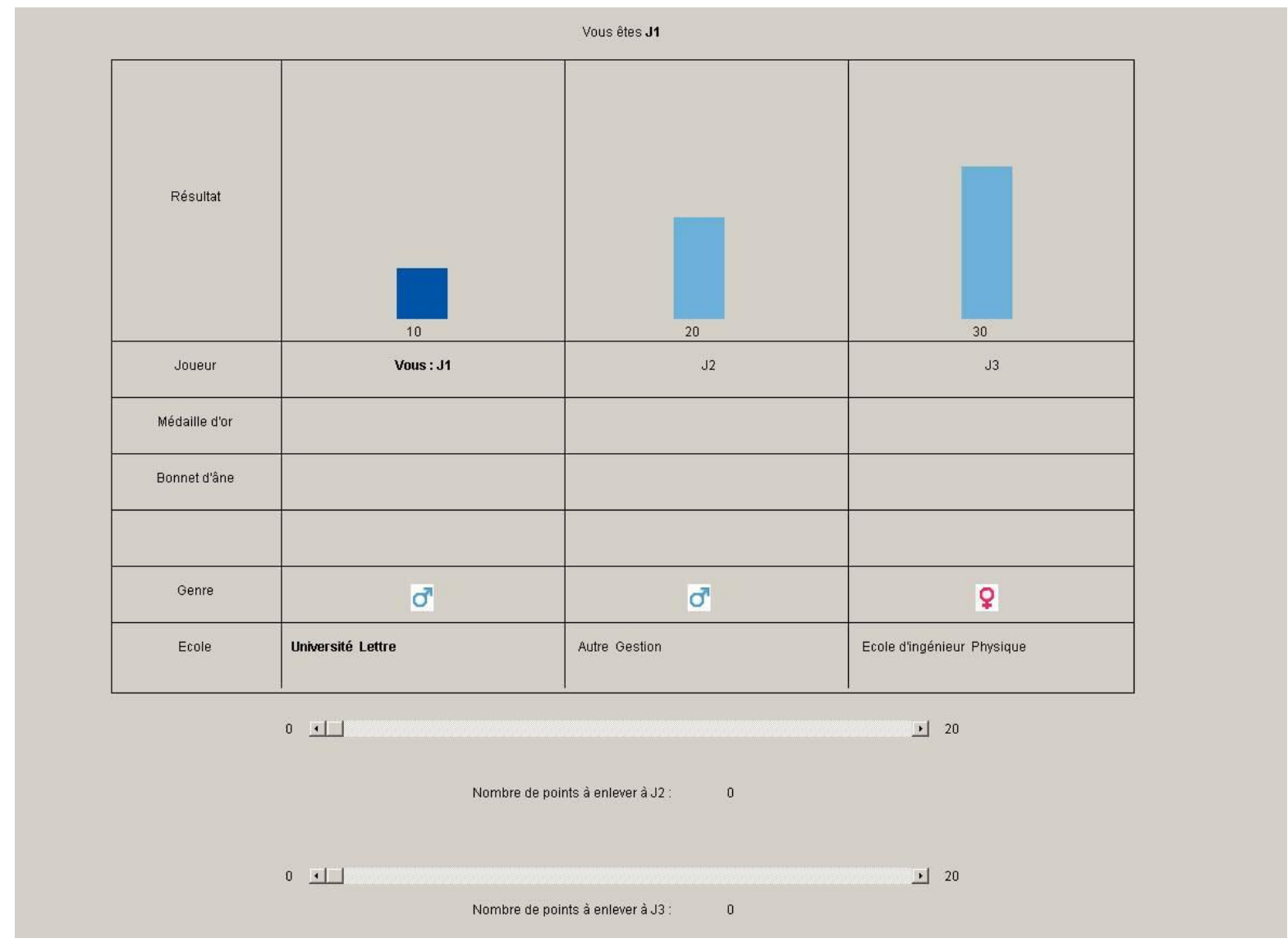

At the end of the second stage, a new graph indicates your final score and the final score of your two group members for this part.

If you have performed the highest score in your group at the end of the second stage, you receive a 'gold medal' on your computer screen. If you have performed the lowest score in your group at the end of the second stage, you receive a 'donkey hat' on your computer screen. If you perform the intermediate score, you receive neither gold medal nor donkey hat. If two group members perform the same score and this score is higher than that of the third member, the first two members do not receive any medal and the third member receives the donkey hat. If their score is lower than that of the third member, the latter receives the gold medal and the two other members do not receive anything.

These gold medals and donkey hats are cumulated across parts.

Beware: the assignment of gold medals and/or donkey hats depends on the final score, i.e. after a possible change of the initial score by the group members.

At the beginning of each new part, the groups of three members are rematched randomly. Therefore, you are matched with two other participants than in the previous part. You are informed at the beginning of each new part of the attributes of the two other group members. These attributes include for each group member his gender, his school, and from the second part on, the number of his gold medals and donkey hats accumulated during the previous parts.

During the experiment, you are allowed to read a book or a magazine that you have brought with you or the magazine that is placed on your desk. You must remain seated and keep silent until the end of the session. You must also press the "Next" button at the beginning of each new part to receive the 10 ECU for this part.

It is forbidden to communicate with the other participants; otherwise, you will be excluded from the session.

If you have any question regarding these instructions, please raise your hand. We will answer to your questions in private. 